\title{
Ecology, Diversity and Taxonomy of the Pteridophytes of Pharenda Forest of Maharajganj District, Uttar Pradesh
}

\author{
Ravi Pratap Gautam¹, S. Dominic Rajkumar ${ }^{2}$, Shobhit Kumar Srivastava ${ }^{3}$, Shashank \\ Kumar Singh $^{4}$, Akhilesh Kumar Gupta ${ }^{5}$ \\ Department of Botany \\ St. Andrew's College, Gorakhpur, Uttar Pradesh \\ dominicrajkumarl@gmail.com
}

\begin{abstract}
Eastern Uttar Pradesh is rich in plant diversity as most of its parts are situated at the foothills of Great Himalaya. The forests of these places are supposed to have abundant diversity of all types of plants from lower forms to higher. Pharenda Forest is one of them. It is a township also known as Anand Nagar situated in Maharajganj district of Uttar Pradesh. Geographically Pharenda is situated between the coordinates $27^{\circ} 06^{\prime} \mathrm{N}$ and $83^{\circ} 17^{\prime}$ E. A survey consisting repetitive field trips was made to learn about the diversity and richness of Pteridophytes of this forest on the basis of effects of climate change. During this study about eleven species of Pteridophytes were collected and morphological observations were made.
\end{abstract}

Keywords: Eastern Uttar Pradesh, plant diversity, Pharenda, Pteridophytes, climate change.

\section{INTRODUCTION}

The Pteridophytes are one of the primitive vascular plants distributed all over the world. India consists of a plenty and diverse pteridophytic flora because of its various climatic conditions and geography. The ferns are found rich in the Himalayas and Western Ghats, as these places are the two hotspots of biodiversity in India. Regarding the number of species Pteridophytes are next to angiosperms. Pteridophytes are an important component of the flora of India. There are about 1200 fern species have been reported from India (Manickam and Irudayaraj 1992, Manickam and Rajkumar 1999, Chandra 2000). Beddome (1883) and Clarke (1880) have done extensive works in early days of Pteridology in India. Pteridophytes have also medicinal properties and it has been used for a long time. The fern flora of Uttar Pradesh has not been properly studied so far. During past several years significant morphological and cytological studies on Pteridophytes of Uttar Pradesh have been done by Rajkumar et. al. (2011a, b, 2012, Srivastava et. al. 2013).

The study area, Pharenda (Fig. 1, also called as Anand Nagar) is a township situated in the district Maharajganj of Eastern Uttar Pradesh. Pharenda is located almost $44 \mathrm{~km}$ north of Gorakhpur and about $55 \mathrm{~km}$ near to the border with Nepal. Geographically Pharenda is situated between the coordinates $27^{\circ} 06^{\prime} \mathrm{N}$ and $83^{\circ} 17^{\prime} \mathrm{E}$ at an average elevation of $88 \mathrm{~m}$. Forest of the Pharenda once upon a time was well known for "Deer". "Sohagi Barwa National Wildlife Sanctuary" is situated in Maharajganj which is about $60 \mathrm{~km}$ far from Pharenda. These forests are basically 'Sal' (Shorea robusta) forests. These forests are moderately thick and sufficient moisture is available for the ferns growing on the forest floor. The soil is rich in humus content due to fallen decaying leaves. Apart from ferns the other floristic diversity is also supposed to be very rich. In general, the climatic conditions pervading this region can broadly be divided into three seasons viz., rainy, winter and summer seasons and the temperature ranging between $3^{\circ} \mathrm{C}$ to $48^{\circ} \mathrm{C}$, relative humidity $35 \%$ to $80 \%$ and rainfall $3 \mathrm{~mm}$ to $250 \mathrm{~mm}$.

\section{Material And Method}

This study is an outcome of repetitive field trips made in Pharenda forest during 2014 and 2015. About eleven species were collected from different localities. The plants were properly processed, poisoned, preserved and herbarium is deposited in the Department of Botany, St. Andrew's College, Gorakhpur for future reference. Detailed morphological and ecological observations were made. 


\section{OBSERVATIONS AND DESCRIPTIONS}

\subsection{Adiantum Lunulatum Burm (Fig.2).}

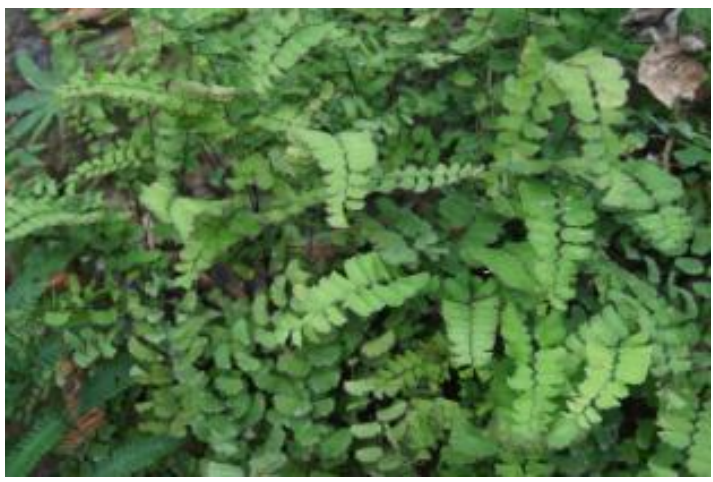

Fig2. Adiantum Lunulatum

Rhizome erect, up to $2 \mathrm{~cm}$ thick; scales ovate- lanceolate, apex acuminate, margin entire. Stipes tufted, wiry, numerous up to $14 \times 0.3 \mathrm{~cm}$, dark brown and black, scaly at the basal most part, glabrous above. Lamina lanceolate, up to $31 \times 6 \mathrm{~cm}$, simply pinnate; pinnae $8-20$ pairs, alternate, distinctly stalked, pinnae fan shaped, up to $5 \times 2.5 \mathrm{~cm}$, dimidiate, upper edge rounded, lobed, margin entire in sterile pinnae; Sori continuous along the edge of the lobe, crescent shaped, spores triangular, $25 \times 31$ $\mu \mathrm{m}$.

Specimens Examined: Adiantum lunulatum; Pharenda Forest; 25.09.2015, 88 m, SACH 651, SACH 663; 23.10.2015, SACH 673.

\subsection{Ampelopteris Prolifera (Retz.) Copel (Fig.3).}

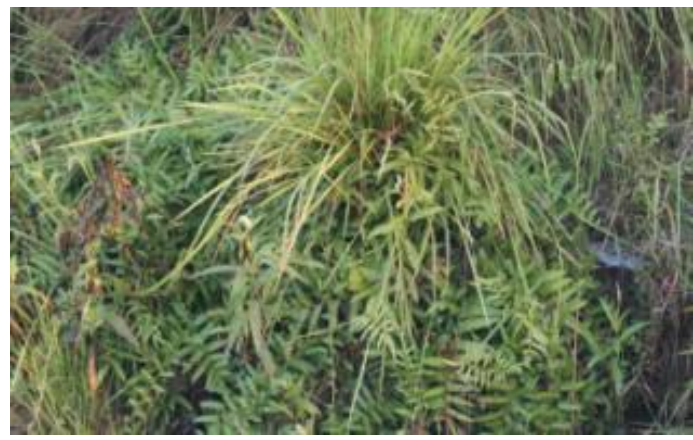

Fig3. Ampelopteris Prolifera

Rhizome wide creeping, up to $1 \mathrm{~cm}$ thick, scaly; Scales $3 \times 1.5 \mathrm{~mm}$ lanceolate, dark brown; Stipes 46 $\times 0.3 \mathrm{~cm}$; Lamina $160 \times 30 \mathrm{~cm}$, simple pinnate, elongated with indefinite growth. Pinnae numerous, alternate \& sub-opposite, sessile, largest pinna $15 \times 2 \mathrm{~cm}$, lanceolate, apex acute, base truncate, margin crenate; Veins 6-8 pairs anastomosing to form a zig -zag excurrent vein; Rachis adaxially grooved, hairy, texture herbaceous; Sori exindusiate, elongate - oblong, superficial; Sporangia short stalked; Spores bilateral, monolete, ovate, $50 \times 28 \mu \mathrm{m}$, exine spinulose.

Specimens Examined: Ampelopteris prolifera; Pharenda Forest; 25.09.2015, 88 m, SACH 652, SACH 664.

\subsection{Ceratopteris Thalictroides (L) Brongn (Fig.4).}

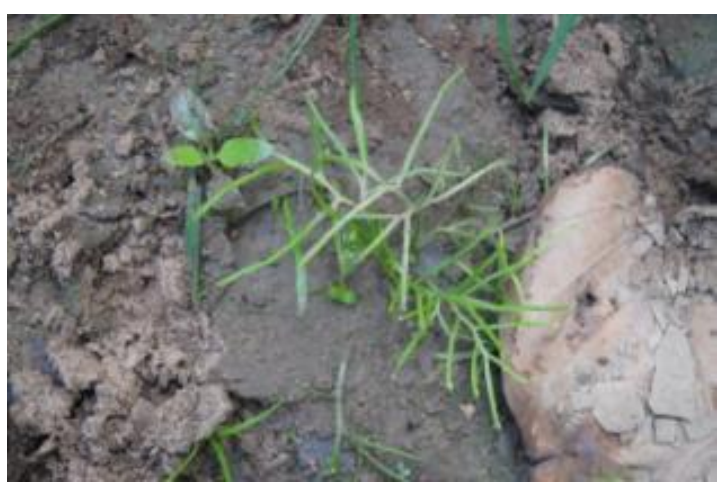

Fig4. Ceratopteris Thalictroides 
Erect, bearing, thick fleshy, long roots densely on the abaxial side, apex covered by scales; scales soft. Uniformly pale brown, about $2 \times 4 \mathrm{~mm}$, ovate, acute, entire, comprising small, curved cell all over. Fronds arranged in rosette; stipes up to $20 \times 1.5 \mathrm{~cm}$, terete, fleshy, pale green, densely ridge all over with few scattered scales. Lamina dimorphous; sterile lamina bipinnatifid or tripinnate, ovate, , acute, cuneate; primary pinnae about five pairs, slightly ascending, alternate, up to $8 \mathrm{~cm}$ apart, distinctly stalked, secondary pinnae about four pairs, alternate, shortly stalked, broadly deltoid or ovate, about 4 $\times 4 \mathrm{~cm}$, pinnatifid about $2-3 \mathrm{~mm}$ to the costa, anastomosing to form rectangular to hexagonal, elongated areoles of up to $0.5 \times 2 \mathrm{~mm}$. Fertile lamina ovate, tripinnate, ultimate segment needle like, up to $6 \times 0.2 \mathrm{~cm}$, acute, margin reflexed and completely covering the lower surface on which two rows of larger sporangia are borne; spores trilete, $120 \mu \mathrm{m}$ in diameter, pale green, exine with thick dense, convexed ridges.

Specimens Examined: Ceratopteris thalictroides; Pharenda Forest; 25.09.2015, 88 m, SACH 653, SACH 665.

\subsection{Christella Dentata (Forssk.) L., (Fig.5).}

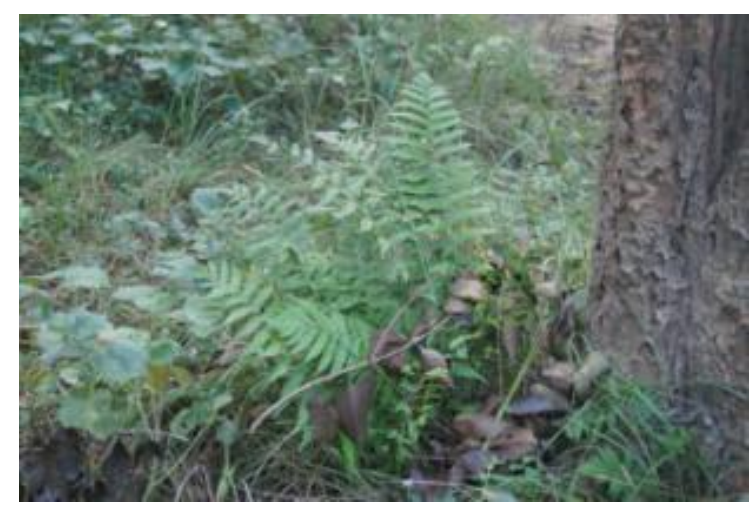

Fig5. Christella Dentata

Rhizome short to long creeping up to $1 \mathrm{~cm}$ thick, sparsely scaly; scales lanceolate, 9 x $1.5 \mathrm{~mm}$, pale brown apex acuminate, margin entire, hairy; stipes up to $2 \mathrm{~cm}$ apart, $75 \mathrm{~cm}$ long $0.5 \mathrm{~cm}$ thick pale brown to dark brown, scaly at the base, glossy and glabrous above. Lamina 90x20 cm, oblonglanceolate; pinnae up to 20 pairs with up to 10 pairs of reduced basal pinnae, reduced basal pinnae opposite or sub opposite, up to $9 \mathrm{~cm}$ apart, unreduced pinnae alternate, $5 \mathrm{~cm}$ apart; largest pinna 19x2 $\mathrm{cm}$, apex acuminate, base broadly cuneate, basal one sub sessile, upper one sessile, margin lobed about half way to the costa; lobes up to 35 pairs, $3.5 \mathrm{~mm}$ wide; veins up to eight pairs, free, one and half pairs of basal veins anastomosing to form an excurrent vein reaching the base of the $2 \mathrm{~mm}$ wide sinus; sinus membrane mostly absent; $1 \mathrm{~mm}$ long, slender, unicellular, acicular hairs densely distributed all over the rachis and upper surface of costs; upper and lower intervenal area with few minute hairs; sori median on veins up to six pairs, up to $1.25 \mathrm{~mm}$ in diameter; indusial with short hairs, spores planoconvex $35 \times 20 \mu \mathrm{m}$, brown, exine with elongate, thick ridges.

Specimens Examined: Christella dentata; Pharenda Forest; 25.09.2015, 88 m, SACH 654, SACH 664, 23.10.2016, SACH 674.

\subsection{Diplazium Esculentum (Retz.) Sw., (Fig.6).}

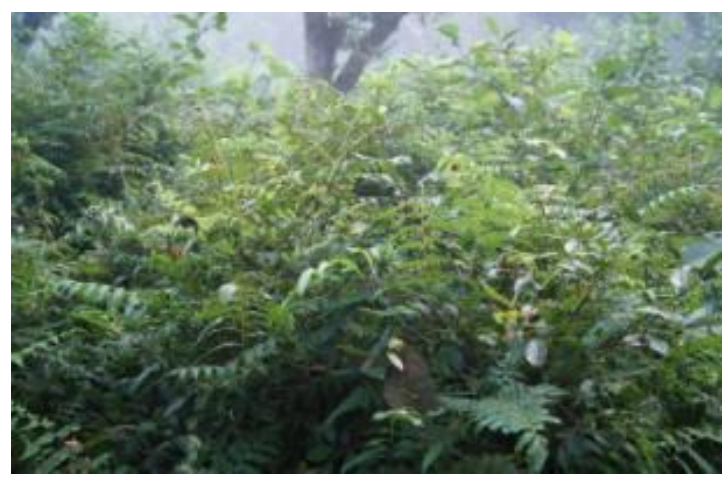

Fig6. Diplazium Esculentum 
Rhizome erect, up to $4 \mathrm{~cm}$ thick, densely scaly at the apex; scales linear lanceolate, $8 \times 1 \mathrm{~mm}$, apex long acuminate, margin with short, simple or bipartite teeth. Stipes tufted, up to $62 \mathrm{~cm}$ long, $8 \mathrm{~mm}$ thick, dark brown or black at the, pale or grey - brown or stramineous above, sparsely scaly at the base, glabrous above; purplish bands scattered throughout the stipe and rachis. Lamina deltoid, up to $110 \times 60 \mathrm{~cm}$ apex acuminate, base truncate, bipinnate with simply pinnate apex; Pinnae up to seven pairs, basal one to two pairs opposite or sub opposite, rest of the pairs alternate, pinnules up to 15 pairs, alternate, basal few pairs sessile, up to $3 \mathrm{~cm}$ apart, oblong lanceolate, up to $11 \mathrm{x} 1.5 \mathrm{~cm}$ apex acuminate, base truncate, margin serrate at the apex, shallowly lobed or crenate in the rest; lobes broadly deltoid, oblique, margin grooved above, veins up to seven pairs, pinnate, veins in the unlobed part of the adjacent groups joining to form an irregular excurrent vein reaching the base of the sinus or the side of the margin of the lobe. Sori up to $1.5 \mathrm{~mm}$ wide, linear, all along the veins except the base and apex; indusial pale brown with margin; spores 50 x $25 \mu \mathrm{m}$, exine densely, finely granulose.

Specimens Examined: Diplazium esculentum; Pharenda Forest; 25.09.2015, 88 m, SACH 655, 23.10.2016, SACH 667.

\subsection{Helminthostachys Zeylanica (L.) Hook., (Fig.7).}

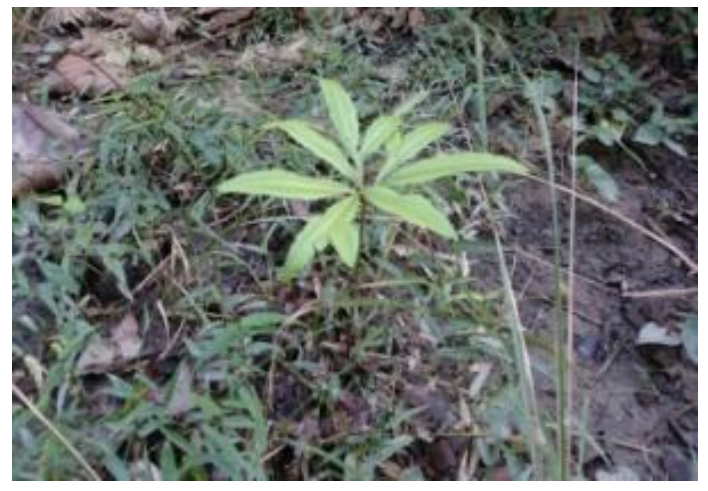

Fig7. Helminthostachys Zeylanica

Rhizome short creeping, up to $1 \mathrm{~cm}$ diameter, tuberous, terete with about $3 \mathrm{~mm}$ thick fleshy roots arranged in two alternate rows on the abaxial side; adaxial side with single row of closely arranged stipe scars; apex covered by oblong, up to $10 \times 7 \mathrm{~mm}$, pale brown entire, rounded scales; stipe solitary, produced annually from the same rhizome, up to $30 \times 0.6 \mathrm{~cm}$, pale brown at the base, greenish above, terete, glabrous. Lamina more or less orbicular in outline, up to $30 \mathrm{~cm}$ in diameter, ternately divided, each branch shortly stalked; lateral branch bears an accessory leaf at the basal basiscopic region, forked equally about $4 \mathrm{~cm}$ above from the base the accessory branches of lateral branches pendent, apex acute base cuneate, margin irregularly wavy with sharp edges; veins distinct both above and below, forked once or twice, free, parallel, up to $1 \mathrm{~mm}$ apart reaching the margin; lamina pale green, glabrous above and below, texture thin herbaceous. Fertile branch solitary, arising from the sterile lamina with $11 \times 0.2 \mathrm{~cm}$ stalk, and $7 \times 0.9 \mathrm{~cm}$ spike; sporangia in small crested clusters forming a loose spike; sporangia in group of four, green group with a small sterile lobe at apex; spores trilete; exine reticulate.

Specimens Examined: Helminthostachys zeylanica; Pharenda Forest; 25.09.2015, 88 m, SACH 656, 23.10.2016, SACH 668.

\subsection{Lygodium Flexuosum (Linn.) Sw., (Fig.8).}

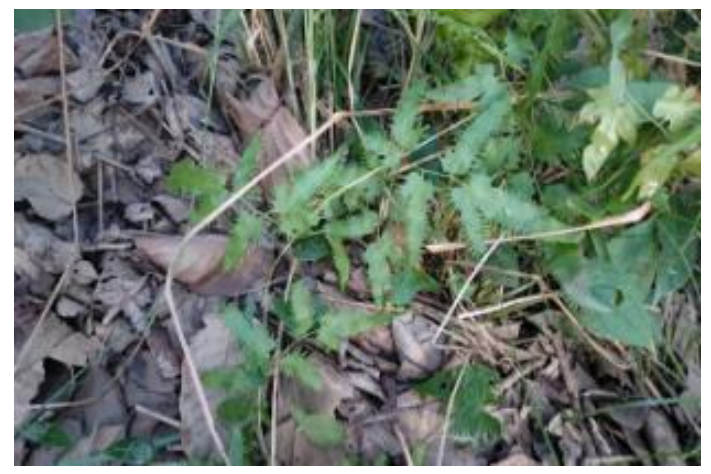

Fig8. Lygodium Flexuosum 
Rhizome short creeping, up to $0.5 \mathrm{~cm}$ thick, densely covered by about $1 \mathrm{~mm}$ long, dark brown, multicellular, uniseriate, tubular hairs all over. Stipes closely arranged, about $50 \mathrm{~cm}$ long, $3 \mathrm{~mm}$ thick, dark brown and densely hairy at the base, stramineous and glabrous above, abaxially rounded, adaxially flattened; fronds oblong- lanceolate; about $80 \mathrm{~cm}$ wide, tripinnate; primary pinnae alternate, about $15 \mathrm{~cm}$ apart with about $3 \mathrm{~mm}$ long common stalk forked once and bearing a dormant bud on the forking axis; each forked branch bears two to three pairs simple or forked pinnules alternately, about 1 $\mathrm{cm}$ apart; pinnules about $10 \times 2.5 \mathrm{~cm}$ oblong lanceolate, simple or forked or auriculated on one or both the bases, apex subacute or acute or acuminate, base cuneate in simple pinnules; margin regularly or irregularly serrulate in sterile pinnules; costa raised above and below; veins distinct above and below, forked thrice or twice, free, reaching the margin; axis of the intervenal area glabrous; pinnule pale green ; texture herbaceous. Sporangia arranged adaxially on about 3 x $1.5 \mathrm{~mm}$ long, fingerlike spikes along the margin of the pinnules; sporangia about five pairs, alternate; protected by indusium; spores about $48 \mu \mathrm{m}$ in diameter; yellowish green.

Specimens Examined: Lygodium flexuosum; Pharenda Forest; 25.09.2015, 88 m, SACH 657, 23.10.2016, SACH 669, SACH 675.

\subsection{Marsilea Minuta L. Mant., (Fig.9).}

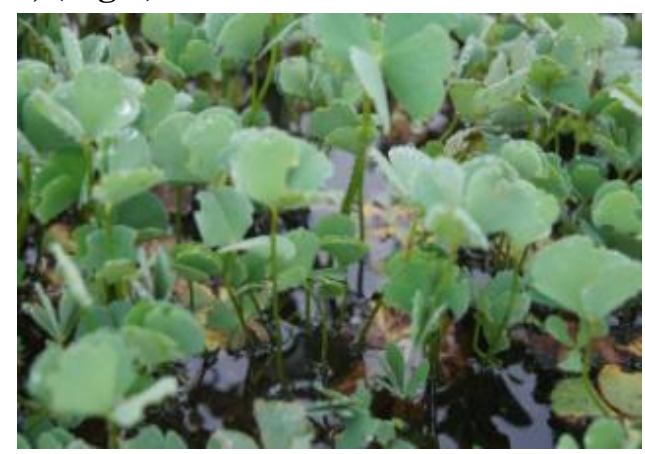

Fig9. Marsilea Minuta

Rhizome long creeping, branched subterranean, about $30 \mathrm{~cm}$. long up to $2 \mathrm{~mm}$ thick, green in plants, pale or dark brown in terrestrials, covered by about $5 \times 0.25 \mathrm{~mm}$, whitish, soft, slender hairs sparsely or densely all over; roots borne usually on nodes, rarely on internodes; Stipes Scattered, about $1 \mathrm{~cm}$ apart, up to $16 \times 0.2 \mathrm{~cm}$, usually green rarely pale or dark brown, terete, glabrous or with few hairs as in rhizome. Leaves four, sessile, arranged at the tip of the stipe in clover leaf model, lateral margin entire, outer margin usually entire, veins distinct above and below, peduncle $7 \times 1 \mathrm{~mm}$; adnate to the peduncle laterally and perpendicularly, more or less bean shaped, up to $5 \mathrm{x} 4 \mathrm{~mm}$, black or dark brown, very hard, densely hairy when young, sparsely or rarely so when mature, slightly, vertically ridged on both convex surfaces; microsporangia and megasporangia enclosed in the same sporocarp and covered by gelatinous layer; microspores yellowish brown, globose, $40 \mu \mathrm{m}$ in diameter with distinct exine and intine; megaspores ovate, up to $0.65 \times 0.5 \mathrm{~mm}$, apex with small pale brown papilla which is surrounded by intine, exine covers all over the surface except papilla, basal region of the megaspores filled with coarse, starch granules and numerous oval -shaped oil globules.

Specimens Examined: Marsilea minuta; Pharenda Forest; 25.09.2015, 88 m, SACH 658, 23.10.2016, SACH 670.

\subsection{Ophioglossum Reticulatum L., (Fig.10).}

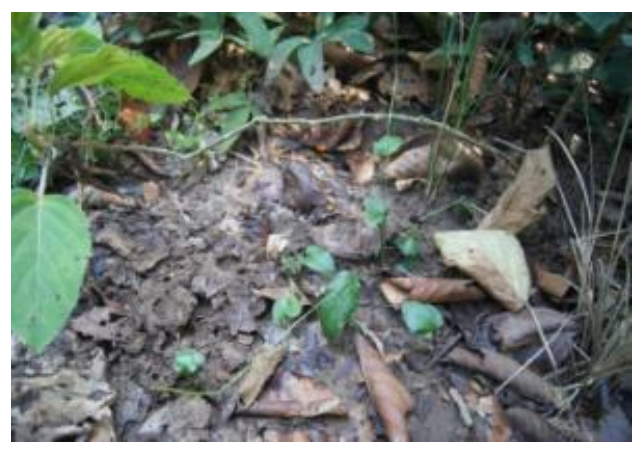

Fig10. Ophioglossum Reticulatum 
Rhizome erect, cylindrical, tuberous, up to $1 \times 0.5 \mathrm{~cm}$, bearing long, thick, fleshy roots and one to two fronds; petiole up to $7 \times 0.2 \mathrm{~cm}$ dark green fleshy, few ovate, about $3 \times 1.5 \mathrm{~mm}$, uniformly pale brown, entire, acute scales present at the very base of the petiole; glabrous above; blade simple , usually cordate, rarely ovate, up to $5 \times 4 \mathrm{~cm}$, subacute or rounded, entire; distinct midrib absent, up to 12 veins passing to the base of the blade; veins copiously anastomosing in the sterile blade to form many sided areoles with one or two included excurrent veins; areoles at the centre of the blade are large and elongated and gradually becoming smaller in size towards periphery; blade dark green, glabrous above and below; texture herbaceous. Spike arising from the base of the sterile blade, oblong- lanceolate, about $3 \times 0.2 \mathrm{~cm}$ with about $6 \times 0.2 \mathrm{~mm}$ long stalk, terminated with 2-3 $\mathrm{mm}$ long triangular sterile tissue, provided with distinct mid vein. Spore sacs arranged in two alternate compact rows, dehisced by horizontal slits; spores spherical, about $40 \mu \mathrm{m}$ in diameter, trilete, colourless with pale green nuclear content, exine with coarse, dense reticulate ridge.

Specimens Examined: Ophioglossum reticulatum; Pharenda Forest; 25.09.2015, 88 m, SACH 659, 23.10.2016, SACH 671, SACH 676.

\subsection{Pteris Biaurita L., (Fig.11).}

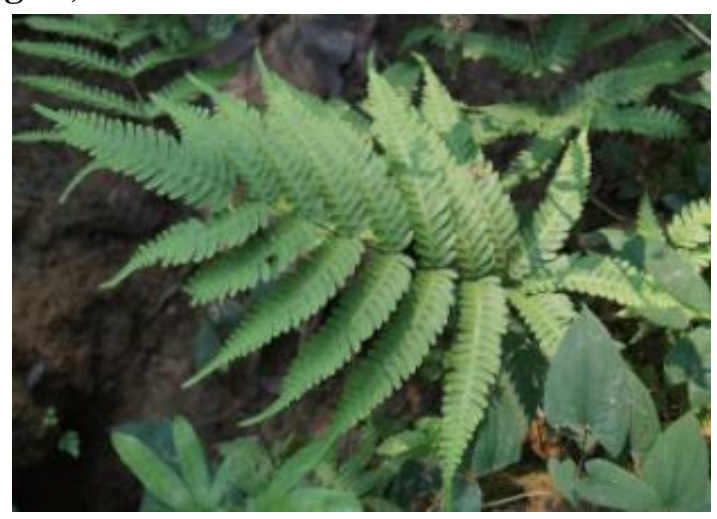

Fig11. Pteris Biaurita

Rhizome erect up to $3 \mathrm{~cm}$ diameter, densely covered by scales at the apex scales lanceolate, $3 \times 0.75$ $\mathrm{mm}$, pale brown ,translucent at the periphery dark brown and opaque at the center, apex acuminate, margin hairy. Stipe tufted, numerous, $36-71 \mathrm{~cm}$ long, 3-7 $\mathrm{mm}$ thick, pale brown at the base, stramineous above, abaxially rounded, adaxially grooved, scaly at the base, glabrous above. Lamina lanceolate, up to $71 \times 40 \mathrm{~cm}$, bipinnatifid; pinnae up to 12 pairs with one or two accessory branch on the basal basiscopic side of the basal most pairs, subopposite ,lanceolate, shortly stalked, apex acuminate, base broadly cuneate, margin lobed within $3 \mathrm{~mm}$ from the costa, lobes oblong slightly falcate, up to $3.3 \times 0.8 \mathrm{~cm}$, apex rounded, margin entire; veins distinct both above and below, basal veins of adjacent costules forming an along costa with five to seven excurrent veins passing to the sinus base, other veins forked once and reaching the margin; pinnae pale green; texture subcorious; small spinule borne at the base of each costule. Sori borne all along the margin except at the base of the sinus and at the apex of the lobes; spores $47 \times 47 \mu \mathrm{m}$, dark brown, exine with dense reticulate thickenings and winged perispore.

Specimens Examined: Pteris biaurita; Pharenda Forest; 25.09.2015, 88 m, SACH 660, 23.10.2016, SACH 672.

\subsection{Pteris Vittata L., (Fig.12).}

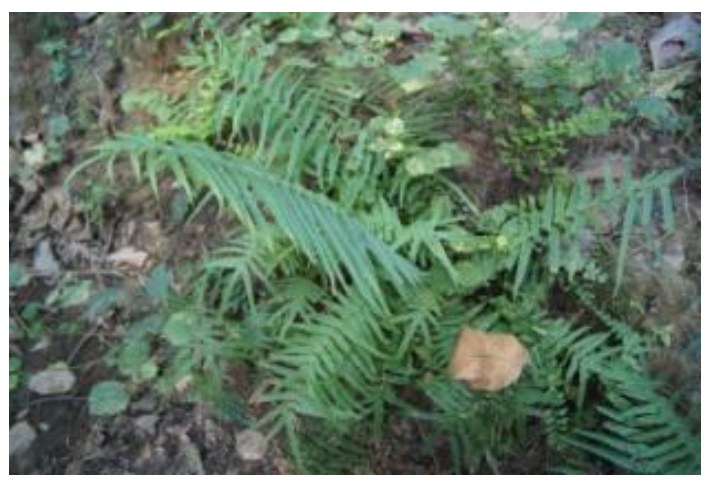

Fig12. Pteris Vittata 
Rhizome sub erect, $5 \mathrm{~cm}$ thick, covered by scales at the apex; scales ovate-lanceolate, $7 \times 8$ $\mathrm{mm}$, thin membranaceous, pale brown, concolorous apex acuminate, margin entire. Stipes tufted, 20 $\mathrm{cm}$ long, $8 \mathrm{~mm}$ thick, abaxially rounded, adaxially grooved, pale brown, scaly at the base, minute, scattered, persistent bases of scales distributed above. Lamina lanceolate, up to 90 x $30 \mathrm{~cm}$, simply pinnate; pinnae up to 35 pairs , opposite or sub opposite, $1.52-2 \mathrm{~cm}$ apart, sessile, linear lanceolate , $20 \times 0.6 \mathrm{~cm}$, apex acuminate, base broadly cuneate, margin serrate in the distal non soral part, entire in the rest; up to 6-10 pairs of basal pinnae progressively reduced to deflexed auricles; veins obscure, simple or forked once, wide apart; pinnae pale green, glabrous; texture herbaceous; sori all along the margin up to the base except the base. Spores, yellowish green with tangled thread like thickenings.

Specimens Examined: Pteris vittata; Pharenda Forest; 25.09.2015, 88 m, SACH 661, SACH 662; 23.10.2016, SACH 677.

\section{Discussion \& CONClusion}

Eleven species of nine genera belonging to seven families were collected during the present study (Table. 1). About nine species were found to be abundant viz; Adiantum lunulatum, Ampelopteris prolifera, Christella dentata, Diplazium esculentum, Lygodium flexuosum, Marsilea minuta, Ophioglossum reticulatum, Pteris biaurita and Pteris vittata, two species viz: Ceratopteris thalictroides and Helminthostachys zeylanica were found to be rare.

Table1. Showing Number of Species with their Respective Families

\begin{tabular}{|l|l|c|}
\hline \multicolumn{1}{|c|}{ FAMILY } & \multicolumn{1}{|c|}{ PLANT SPECIES } & No. OF SPECIES \\
\hline Adiantaceae & Adiantum lunulatum & 1 \\
\hline Parkeriaceae & Ceratopteris thalictroides & 2 \\
\hline Pteridaceae & $\begin{array}{l}\text { Pteris biaurita } \\
\text { Pteris vittata }\end{array}$ & 2 \\
\hline Ophioglossaceae & $\begin{array}{l}\text { Helminthostachys zeylanica } \\
\text { Ophioglossum reticulatum }\end{array}$ & 1 \\
\hline Schizaeceae & Lygodium flexuosum \\
\hline Thelypteridaceae & $\begin{array}{l}\text { Ampelopteris prolifera } \\
\text { Christella dentate } \\
\text { Diplazium esculentum }\end{array}$ & 3 \\
\hline Marsileaceae & Marsilea minuta & 1 \\
\hline
\end{tabular}

The eleven species collected have been classified on the basis of their occurrence (Table. 2).

Table2. Showing Fern Species on the Basis of their Occurrence at Different Ecological Habitats

\begin{tabular}{|r|l|c|c|c|}
\hline \multirow{2}{*}{ S. No. } & \multicolumn{1}{|c|}{ SPECIES } & \multicolumn{3}{c|}{ ECOLOGICAL HABITAT } \\
\cline { 3 - 5 } & & Forest Floor Fern & Road Side Fern & Aquatic \\
\hline $\mathbf{1 .}$ & Adiantum lunulatum & + & + & \\
\hline $\mathbf{2 .}$ & Ampelopteris prolifera & + & & \\
\hline $\mathbf{3 .}$ & Ceratopteris thalictroides & + & + & + \\
\hline $\mathbf{4 .}$ & Christella dentata & + & & \\
\hline $\mathbf{5 .}$ & Diplazium esculentum & + & & \\
\hline $\mathbf{6 .}$ & Helminthostachys zeylanica & + & & + \\
\hline $\mathbf{7 .}$ & Lygodium flexuosum & + & & \\
\hline $\mathbf{8 .}$ & Marsilea minuta & + & + & \\
\hline $\mathbf{9 .}$ & Ophioglossum reticulatum & + & + & \\
\hline $\mathbf{1 0}$. & Pteris biaurita & + & + & \\
\hline $\mathbf{1 1}$. & Pteris vittata & & & \\
\hline
\end{tabular}

Ecological observation made based on their occurrence at different habitats shows that about four species (Adiantum lunulatum, Christella dentata, Pteris biaurita and Pteris vittata) were found to be present in both the forest floor as well as on the road side. Five species (Ampelopteris prolifera, Diplazium esculentum, Helminthostachys zeylanica, Lygodium flexuosum and Ophioglossum reticulatum) were found to grow well on forest floor only. Two species (Ceratopteris thalictroides and Marsilea minuta) were found to be aquatic. 


\section{ACKNOWLEDGEMENTS}

The authors are thankful to Rev. Dr. J. K. Lal, Principal, St. Andrew's College, Gorakhpur for the encouragement and for providing all the necessary facilities. One of the authors RPG is thankful to UGC-RGNF scheme for providing financial support.

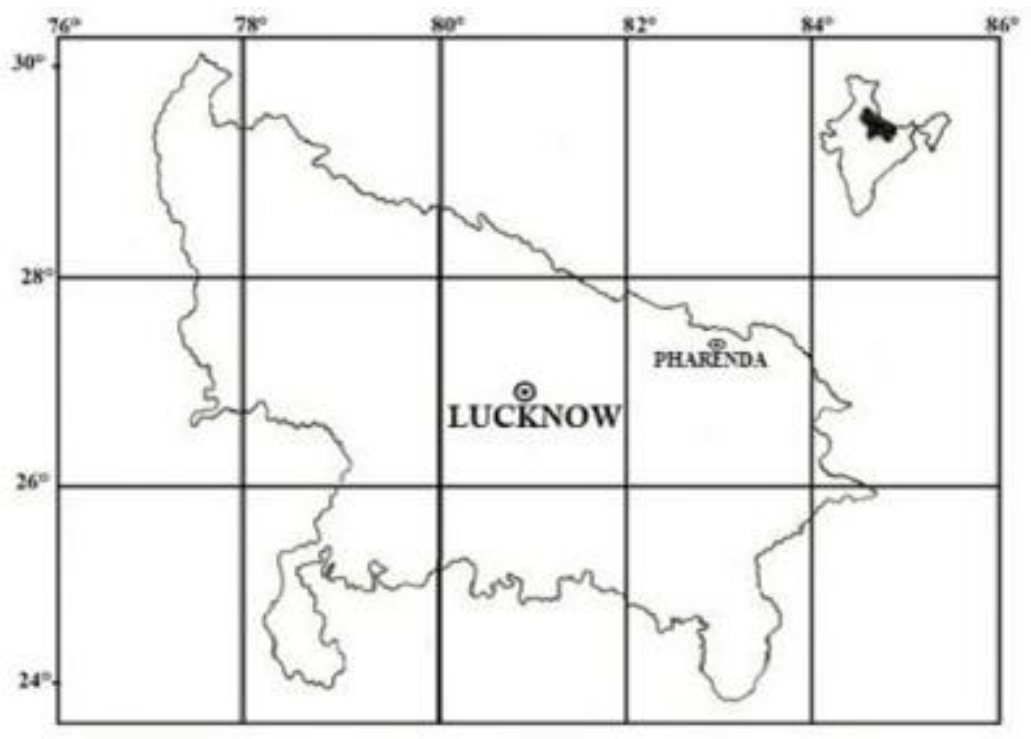

Fig1. Map of Area of the Study

\section{REFERENCES}

[1] Beddome, R. H. (1883). A handbook to the Ferns of British India, Ceylon and Malaya Peninsula. Thacker Spink \& Co Calcutta.

[2] Chandra, S. (2000). The ferns of India (Enumeration, Synonyms and Distribution), Int. Book Distr. Dehradun, India, Pp-459.

[3] Clarke, C. B. (1980). A review of the ferns of Northern India. Trans. Linn. Soc. Lond. 2 Bot., 1:425-619.

[4] Manickam, V. S. and Irudayaraj, V. (1992). Pteridophyte flora of the Western Ghats, South India, B.I. publications New Delhi.

[5] Manickam, V.S. and Rajkumar, S.D. (1999). Polymorphic ferns of the Western Ghats South India. Bishen Singh Mahendra Pal Singh publication, Dehra Dun, India.

[6] Rajkumar, S. D., Gautam R. P., Singh S. K., Srivastava, S. K. and Gond, D. K. (2011) a. Ampelopteris prolifera (retz.) Copel. and Sphaerostephanos unitus (1.) Holttum: two new records of Thelypteroid ferns from Uttar Pradesh. Journal of Forestry, Dehradun. Vol. 34(2): 225-228.

[7] Rajkumar, S.D. Singh, S.K. Gautam, R.P. and Srivastava, S.K. (2011)b. Pteris vittata Linn., A New Record to the Genus Pteris (Pteridaceae-Pteridophyta) from Uttar Pradesh. International Journal of Biological Technology. (Special Issue): 149-151.

[8] Rajkumar S. D., Singh S. K.,Srivastava S. K., and Gautam R. P. 2012. Adiantum aethiopicum and Lygodium flexuosum (Linn.) Swartz: Two new Records of rare ferns from Uttar Pradesh. Pteridological Research, Gayathiri Technological Research and Publication. Vol.1 (2): 5-7.

[9] Srivastava S. K., Rajkumar S. D., Singh S. K., and Gautam R. P. 2013. Medicinal diversity of the family Adiantaceae (Presl) Ching (Pteridophyta) of Eastern Uttar Pradesh. International Journal of Research in Engineering and Biosciences. Vol.1 (Special Issue 1): 25-29. 